\title{
THE CHRONOLOGY OF 'TOM
} JONES.'

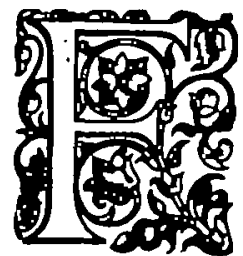

ROM certain passages in 'Tom Jones' it is possible to construct a chronology of the novel, and to follow events with accuracy from day to day, from the date clusion of the story. When Jones meets the soldiers at Hambrook it is said that, "This was the very time when the late rebellion was at the highest ; and indeed the banditty were now marched into England' (Bk. vii, ch. I I). Now Charles crossed the border on 8th November, 1745, and on the $14^{\text {th }}$ Carlisle surrendered. On $4^{\text {th }}$ December the rebels entered Derby, but two days later the retreat began and continued until Charles crossed the Esk into Scotland on 2oth December. Manifestly, therefore, Jones must have been at Hambrook some time between 8 th November and 6th December, 1745 .

Now, three days after Jones left Hambrook he marched out of Gloucester as the clock struck five, ' an hour at which (as it was now mid-winter) the dirty fingers of night would have drawn her sable curtain over the universe had not the moon forbid her, who now with a face as broad and red as those of some jolly mortals, who, like her, turn night 


\section{CHRONOLOGY OF 'TOM JONES.' 219}

into day, began to rise from her bed' (Bk. viii, ch. 9). Consulting a London Almanac for I 745 , we find that the moon, which was at the full on 28th November, at I a.m., rose at 4.48 p.m., Greenwich time, on 29th November, and at Gloucester it would be just nine minutes later, or 4.57. The moon rose at 5.11 p.m., on 29 th October, and at 4.29 p.m., on 28th December, and obviously one of these dates is too early and the other too late to fit in with the author's remarks about the rebellion, so that $\mathrm{Mr}$. Jones must have left Gloucester on 29th November, I 745.

Confirmation of the state of the moon at this time is to be found in widely separated portions of the story. Thus Mrs. Waters left Worcester at five the next morning, November 3 oth, ' it being above two hours before day, but the moon, which was then at the full gave them all the light she was capable of affording '(Bk. ix, ch. 7). On that day the sun rose at nine minutes past eight, but there would be partial daylight nearly an hour earlier. Also it was early the next morning, ist December, that Sophia fell from her horse, "but the shadows of the trees and a friendly cloud obscured the moonlight, and so preserved her from confusion' (Bk. xi, ch. 2).

Now, there is one palpable error in the chonology of 'Tom Jones.' On the eve of the battle between Jones and Twackum the author says, 'it was now a pleasant evening in the latter part of June' (Bk. v, ch. 10), while according to the book headings, after a lapse of but three weeks and five days it is midwinter (Bk. viii, ch. 9). 


\section{THE CHRONOLOGY OF}

This anachronism was first pointed out by a correspondent in the 'Gentleman's Magazine' for May, 1791, who signs himself 'Hinc Inde.' No reply can be made to this, save to acknowledge the error, but from the beginning of the story up to the date of Mr. Allworthy's illness, the author only attempted to give the important happenings in the life of Tom Jones, whereas from this time on the adventures of his people are given carefully from day to day, and this error crept in at the very beginning of this change of method. The events described in this chapter could not have happened in June, and according to our chronology, must have taken place on 3 rd November, but other than this one inadvertence there is nothing to mar the wonderful harmony in the chronology of the story.

The Man of the Hill was born in 1657 . This Fielding tells us, but he does not call our attention to the fact that the night Jones met him he had reached the ripe age of eighty-eight. As Mrs. Deborah Wilkins was fifty-two on the finding of Tom Jones, she must have been born in 1672, and was therefore seventy-three when she complained of not being mentioned by name in Mr. Allworthy's will. But there was worse in store for her than that, for her creator never mentioned her again, save to recount her doings at the time of Tom's birth. As the Lieutenant was near sixty years of age in 1745 he must have been born about 1685 , and was twenty-one when promoted by Marlborough at the battle of Ramilles, or Tannieres, as Fielding calls it. Partridge was born about 1694 , married in 1715 , his wife died in 1724 , he was 
fifty-one when he joined Jones in his travels, and was thirty-three years older than Molly Seagrim, his second wife. Jenny Jones went to live with the Partridges in 1720 , and lived with an unnamed admirer from 1724 until his death in 1736 . She lived after that with Captain Waters until he departed for the wars on 29th November, 1745. If she was fifteen when she went to the Partridge's, she would have been forty years of age when she met Tom Jones at Upton. Mrs. Allworthy died in 1719; and Squire Western's niece, Harriet, was born in 1722 , and was married to Brian Fitzpatrick in 1740. Tom Jones was born in the latter part of April, or early in May, 1724. Sophia was born in 1726, and Molly Seagrim in 1727. Sophia's mother died in 1737 , and it was in 1739 that Blifil released Sophia's bird.

It was about June, 1745 , that Partridge returned from Ireland, and about ist Oetober that he settled in the village where he met Jones. Mr. Allworthy turned Jones out-of-doors on 24th November. Sophia left home on 3 oth November, and arrived in London $3^{\text {rd }}$ December. Jones rescues Mrs. Waters on 3 oth November, and takes her to Upton. On 2nd December, he arrives at the inn on the London Road, and reaches London on the

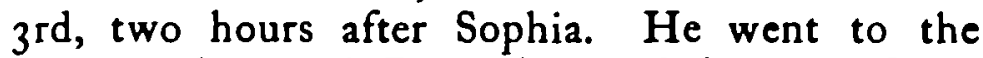
masquerade on $7^{\text {th }}$ December, and there met Lady Bellaston, who dismissed him finally on the 18 th, a period of eleven days. Fellamar attacked Sophia, and Squire Western arrived in London on the I 7 th. Nancy Miller was married to Jack Nightengale on the 18 th. On the 21st Jones and 
Partridge saw Garrick in 'Hamlet,' and the same evening Mr. Allworthy and Blifil arrived in London. In the last book, the eighteenth, Fielding hastens to his conclusion, and it is impossible properly to distribute all the events of these six days; but Allworthy called on old Nightengale on 26th December, Jones returned from jail and met Sophia on the 28 th, was married on the 29 th, and the whole party returned to the country on the last day of 1745 , the 3 ist.

The fact that Fielding made this slip in writing 'June' for ' November' indicates very clearly that he did not reduce his chronology to writing, but carried the whole in his head, and thus accomplished a feat which has not been approached, nor indeed attempted by any other writer of fiction. That he did not depend on a calendar is shown even more positively by the fact that in his story he totally ignores the existence of Sunday, there being no mention of the day save when Molly has her battle in the churchyard. This he could not have failed to notice had he depended in the least upon an almanac. Had he had a calendar before him he would never have permitted so pious a man as Mr. Allworthy to turn Jones adrift on the Sabbath day, 24th November, nor would Squire Western have met a pack of hounds in full cry on Sunday, Ist December. Surely Jones would not have expected Partridge to get a $£ 50$ note changed in London on Sunday morning, nor would Sophia have been at the theatre on Sunday, $15^{\text {th }}$ December. Then again Fielding, had he realized it, could scarcely have avoided calling attention to the 
fact that the day of Jones's deepest distress, the day he was told that the sailors insisted that he struck the first blow that brought on the duel with Fitzpatrick, the day that he learns that Mrs. Waters was no other than Jenny Jones, his reputed mpther, that this day of utter humiliation and despair was Christmas.

But, after all, the discrepancies are negligible in comparison with the harmonies disclosed, as we rearrange the events in order of time. Thus we find Lady Bellaston angrily dismissing Jones on 18 th December, and later on the same day we find her suggesting that Fellamar might have Jones pressed as a vagabond and sent to sea. The first of these events is told in Book xv, chapter 9, and the other in Book xvi, chapter 8, more than eighty pages intervening in the first edition. The connection between these two events could not have been the result of accident, yet the author fails to call our attention to it. Then on I6th December, Lady Bellaston failed to keep an appointment with Jones (Bk. xiv, ch. 5), and when Jones chides her for this she gives but a vague excuse (Bk. xv, ch. 7) ; but on the evening in question she had a suddenly planned dinner and card party, in furtherance of her plot against Sophia (Bk. xv, ch. 3), and this, of course, she could not confide to Jones, and the author again leaves us to discover the truth. Again on 2ist December, Mrs. Fitzpatrick calls upon Squire Western, and later on Mrs. Western, and is received with brutality, crude or refined, by both. Smarting under this rebuff, on the evening of the same day, 


\section{CHRONOLOGY OF 'TOM JONES.'}

she spies Jones at the play, and asks him to call upon her, in the hope that she can induce him to join in her wild plot for the humiliation of her aunt, and as before, Fielding fails to call attention to the connection between these events. All the way through Fielding seems to be recounting real happenings, and his omissions and errors are only such as would be expected were this actually the case.

Frederick S. Dickson. 